\title{
Water productivity mapping methods using remote sensing
}

\author{
Chandrashekhar M. Biradar, ${ }^{\mathrm{a}, b^{*}}$ Prasad S. Thenkabail, ${ }^{\mathrm{c}, \mathrm{d}}$ Alexander \\ Platonov, ${ }^{\mathrm{d}}$ Xingming Xiao, ${ }^{\mathrm{a}, \mathrm{b}}$ Roland Geerken, ${ }^{\mathrm{e}}$ Praveen Noojipady, ${ }^{\mathrm{f}}$ \\ Hugh Turral, ${ }^{\mathrm{g}}$ Jagath Vithanage ${ }^{\mathrm{d}}$ \\ ${ }^{a}$ Center for Spatial Analysis, College of Atmospheric and Geographic Science, University of \\ Oklahoma, Norman, OK 73019, USA \\ chandra.biradar@ou.edu; xiangming.xiao@ou.edu \\ ${ }^{\mathrm{b}}$ Complex Systems Research Center, Institute for the Study of Earth, Oceans and Space, \\ University of New Hampshire, Durham, NH, 03824, USA \\ ${ }^{\mathrm{c}}$ United States Geological Survey (USGS), Flagstaff, AZ 86001, USA \\ pthenkabail@usgs.gov; thenkabail@gmail.com \\ ${ }^{\mathrm{d}}$ International Water Management Institute (IWMI), HQ, PO Box 2075, Colombo, Sri Lanka \\ a.platonov@cgiar.org; j.vithanage@cgiar.org \\ ${ }^{\mathrm{e}}$ Department of Geology and Geophysics, Yale University, New Haven, CT 06520, USA \\ roland.geerken@yale.edu \\ ${ }^{\mathrm{f}}$ Department of Geography, University of Maryland, College Park, MD 20742, USA \\ pnoojipa@umd.edu \\ ${ }^{\mathrm{g}}$ On the Street Productions, 28 Newry Street, North Carlton, Melbourne 3054, Australia \\ hugh.turral@gmail.com \\ *Corresponding Author: Center for Spatial Analysis, Stephenson Research and Technology \\ Center, 101 David L. Boren Blvd. Norman, OK 73019, USA \\ chandra.biradar@ou.edu
}

\begin{abstract}
The goal of this paper was to develop methods and protocols for water productivity mapping (WPM) using remote sensing data at multiple resolutions and scales in conjunction with field-plot data. The methods and protocols involved three broad categories: (a) Crop Productivity Mapping (CPM) (kg/m2); (b) Water Use (evapotranspiration) Mapping (WUM) (m3/m2); and (c) Water Productivity Mapping (WPM) (kg/m3). First, the CPMs were determined using remote sensing by: (i) Mapping crop types; (ii) modeling crop yield; and (iii) extrapolating models to larger areas. Second, WUM were derived using the Simplified Surface Energy Balance (SSEB) model. Finally, WPMs were produced by dividing CPMs and WUMs. The paper used data from Quickbird $2.44 \mathrm{~m}$, Indian Remote Sensing (IRS) Resoursesat-1 23.5m, Landsat-7 30m, and Moderate Resolution Imaging Spectroradiometer (MODIS) $250 \mathrm{~m}$ and $500 \mathrm{~m}$, to demonstrate the methods for mapping water productivity (WP). In terms of physical water productivity (kilogram of yield produced per unit of water delivered), wheat crop had highest water productivity of $0.60 \mathrm{~kg} / \mathrm{m} 3$ (WP), followed by rice with $0.5 \mathrm{~kg} / \mathrm{m} 3$, and cotton with $0.42 \mathrm{~kg} / \mathrm{m} 3$. In terms of economic value (dollar per unit of water delivered), cotton ranked highest at $\$ 0.5 / \mathrm{m} 3$ followed by wheat with $\$ 0.33 / \mathrm{m} 3$ and rice at $\$ 0.10 / \mathrm{m} 3$. The study successfully delineated the areas of low and high WP. An overwhelming proportion $(50+\%)$ of the irrigated areas were under low WP for all crops with only about $10 \%$ area in high WP.
\end{abstract}

Keywords: water productivity mapping, biophysical relationship, vegetation indices, evapotranspiration, remote sensing.

\section{INTRODUCTION}

Considerable increases in land and water productivity have resulted from agricultural intensification using "green revolution" technologies of short season varieties, artificial 
nitrogen fertilizer, and irrigation water. The world's population continues to grow rapidly, at a time when water resources are heavily utilized and there is a strong emerging likelihood that water resources will decrease and become more precarious under the impacts of global climate change. Consequently, a new challenge is to raise total agricultural production using no more water than at present, and preferably less. Fresh water withdrawals for agriculture account for nearly $80 \%$ of the total water withdrawal from surface water and groundwater [1]. However, competition for water is now arising across sectors as well as within agriculture, including: (a) increased demands of urbanization, industries, (b) growing more food for increasing population (globally about 100 million additional population every year), (c) needs of environmental flows and recreation, (d) growing needs of biofuel crops, (e) increased calorie intake per capita in emerging economies, and (f) change in food habits of the people through increased luxury consumption of fruits and vegetables in more mature economies. The spatial distribution of water in the world is highly uneven, so that water scarcity is more acute in some regions than others, notably the arid and semi arid tropics. All these factors call for development of new technologies for better water productivity (more crop per drop). Increasing water productivity requires a different approach to agricultural management, to optimize the use of inputs and management whilst at the same time understanding that land resources are also limited, which means that a simple strategy of increasing land area with lower yield but higher water productivity is not a solution in most cases.

The first step in improving performance is to understand the levels, distribution and patterns of water productivity. This will help us to pin-point areas of high and low WP and analyze the reasons for variability. This in turn, allows diagnosis of the reasons for low water productivity which can then be tackled through research and improved land and water management. Commonly water productivity is assessed at plot or field level, or determined from secondary crop statistics and water supply or water use data, but actual water use (evapotranspiration) may be unknown [2]. Remote sensing science offers the possibility of both greater coverage, and greater spatial detail in mapping water productivity, through the use of emerging techniques to map and model crop growth and water use, through synoptic coverage over large areas at regular time intervals. Remote sensing data is now available in multiple spatial, radiometric and spatial resolutions. .

The main goal of this research was to develop methods for WPM using remote sensing data at various spectral, spatial, and radiometric resolutions. The focus was on irrigated areas. Specific objectives include: (a) developing methods and protocols for WPMs using remote sensing data of various resolutions, (b) extrapolating (up-scaling) using the best models to understand WP variations over space and time; and (c) studying accuracies and errors involved in WP across scales (or resolutions), radiometry, and bandwidth.

\section{METHODS}

\subsection{Definition of water productivity}

Water productivity (WP) is defined as the kilogram of yield produced $/ \mathrm{m}^{3}$ of water depleted by the crop or, alternatively, as value in dollar of yield produced $/ \mathrm{m}^{3}$ of water depleted [3].

$$
\begin{gathered}
\mathrm{WP}\left(\mathrm{kg} / \mathrm{m}^{3}\right)=\frac{\text { Yield }\left(\mathrm{kg} / \mathrm{m}^{2} \text { or } \mathrm{kg} / \text { pixel }\right) \text { or economic value }(\$)}{\text { Water use or } \mathrm{ET}_{\text {actual }}\left(\mathrm{m}^{3} / \mathrm{m}^{2} \text { or } \mathrm{m}^{3} / \text { pixel }\right)} \\
\text { Where, } \mathrm{ET}_{\text {actual }}\left(\mathrm{m}^{3}\right)=\mathrm{ET}_{\text {fraction }}(\text { dimensionless }) * \mathrm{ET}_{\text {potential }}\left(\mathrm{m}^{3}\right)
\end{gathered}
$$




\subsection{Study area}

The study area was selected after discussions with local experts in the Syr Darya river basin in Central Asia (Fig. 1). The area called Galaba was selected because it represents the irrigated areas of the entire Syr Darya river basin well, in terms of the following characteristics. Cotton, wheat and rice are the main crops grown in the basin. Cotton accounts for nearly 55 percent of sown area and is the dominant crop. Wheat was the second-most favored crop, covering nearly 30 percent of the area, but it cannot be grown at the same time as cotton because cotton planting has to be completed before wheat can be harvested. As a result many units adopt a two-year rotation system, planting wheat after cotton and leaving the field fallow, planting maize or another short-growing crop after the wheat. Small patches of paddy rice and alfalfa are irregularly distributed across the basin and gardens form a an important part of every household. The rainfall in Galaba varies between 100 and $200 \mathrm{~mm}$ per year. The average temperature is $0-4^{\circ}$ Celsius in January and $28-32^{\circ}$ Celsius in July.

The irrigation system in this region is one of the most complex man-made water systems in the world [4]. Virtually all the available surface water has been diverted to irrigation and so there is little scope for further expansion of irrigated area to meet the increasing food demand in the region. Increased water productivity (WP) is the preferred option to meet future food demand in this region. The Galaba study area was covered by a Quickbird image with an area of 6575 hectares (ha).

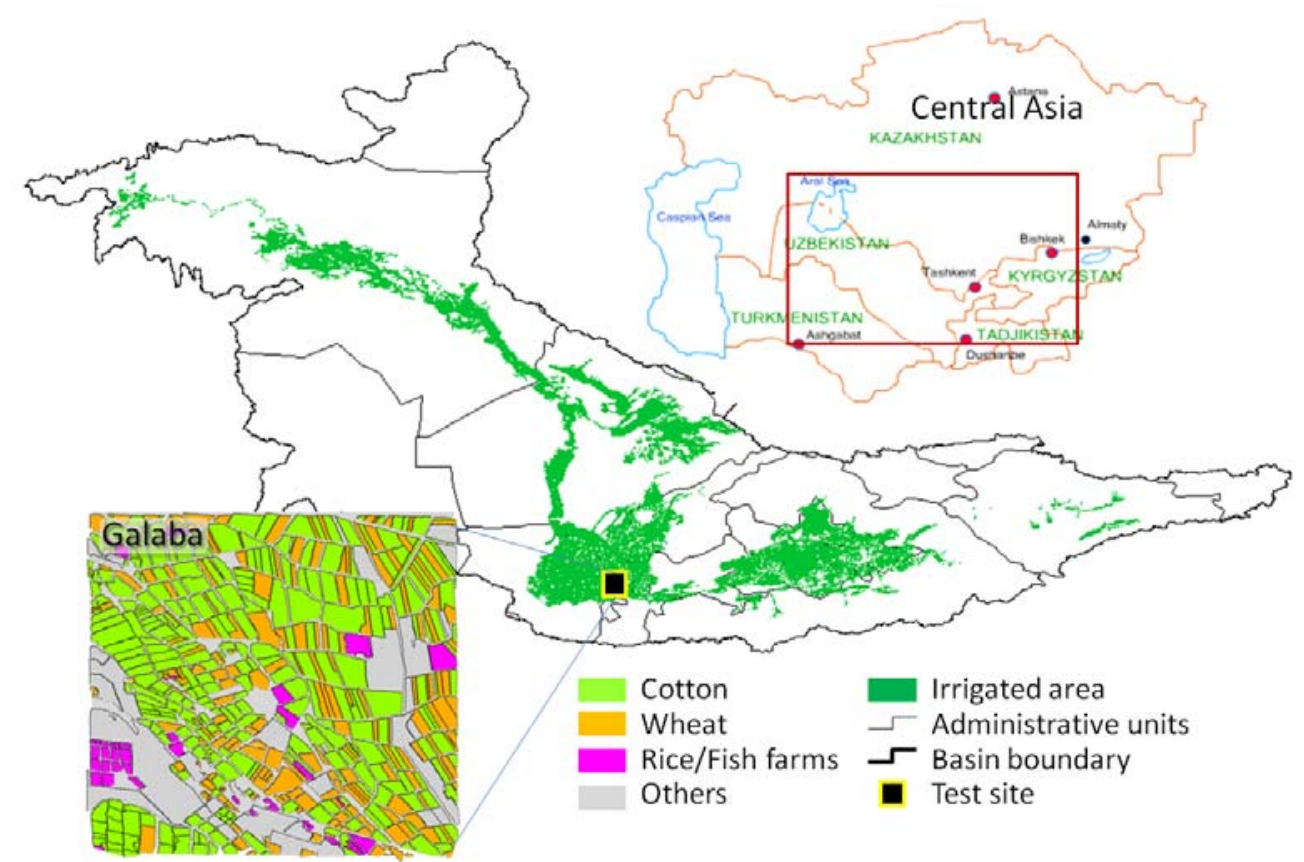

Fig. 1. Location of study area: a representative site called Galaba in the Syr Darya river basin. 
Table 1. Characteristics of remote sensing data sets used in this study.

\begin{tabular}{|c|c|c|c|c|c|c|c|}
\hline \multirow[t]{2}{*}{ Sensor } & \multicolumn{3}{|l|}{ Resolution } & \multirow{2}{*}{$\begin{array}{l}\text { Band range } \\
(\mu \mathrm{m})\end{array}$} & \multirow{2}{*}{$\begin{array}{l}\text { Irradiance } \\
\left(\mathrm{W} \mathrm{m}^{-2} \mathbf{s r}^{-1}\right. \\
\left.\mu \mathrm{m}^{-1}\right)\end{array}$} & \multirow{2}{*}{$\begin{array}{l}\text { Revisit } \\
\text { (days) }\end{array}$} & \multirow[t]{2}{*}{ Acquisition dates } \\
\hline & $\begin{array}{l}\text { Spatial } \\
\text { (m) }\end{array}$ & $\begin{array}{l}\text { Spectral } \\
\text { (m) }\end{array}$ & $\begin{array}{l}\text { Radiometric } \\
\text { (bit) }\end{array}$ & & & & \\
\hline 1.Quickbird & $\begin{array}{l}0.61 \\
\text { (Panchromatic); } \\
2.44 \\
\text { (Multispectral) }\end{array}$ & 4 & 11 & $\begin{array}{l}0.45-0.52 \\
0.52-0.60 \\
0.63-0.69 \\
0.76-0.8\end{array}$ & $\begin{array}{l}1381.79 \\
1924.59 \\
1843.08 \\
1574.77\end{array}$ & 5 & July 26, 2006, August 3, 2006 \\
\hline $\begin{array}{l}\text { 2. IRS-P6- } \\
\text { LISS3 }\end{array}$ & 23.5 & 4 & 10 & $\begin{array}{l}0.52-0.59 \\
0.62-0.68 \\
0.77-0.86 \\
1.55-1.7\end{array}$ & $\begin{array}{l}1857.7 \\
1082.4 \\
1556.4 \\
1082.4\end{array}$ & 24 & $\begin{array}{l}2006 \text { (June 5, June } 15 \text {, June } 20 \text {, } \\
\text { July 9, July 14, July 18, August } \\
\text { 26, September } 24 \text {, October } 27 \text {, } \\
\text { November 6), 2007(April 13, } \\
\text { May 26,June 19, July 18) }\end{array}$ \\
\hline $\begin{array}{l}\text { 3. Landsat } \\
\text { ETM+ }\end{array}$ & $\begin{array}{l}14.25 \\
\text { (Panchromatic); } \\
28 \\
\text { (Multispectral); } \\
\text { and } 60 \\
\text { (Thermal) }\end{array}$ & 8 & 8 & $\begin{array}{l}0.45-0.515 \\
0.525-0.605 \\
0.63-0.690 \\
0.75-0.90 \\
1.55-1.75 \\
10.40-12.5 \\
2.09-2.35\end{array}$ & $\begin{array}{l}0.483 \\
0.565 \\
0.660 \\
0.825 \\
1.650 \\
11.45 \\
2.220\end{array}$ & 16 & $\begin{array}{l}2006 \text { (April 24, May 10, June } \\
\text { 11, July 29, August 14, October } \\
\text { 1) }\end{array}$ \\
\hline $\begin{array}{l}\text { 4. MODIS } \\
\text { (MOD09Q1) }\end{array}$ & 250 & 2 & 12 & $\begin{array}{l}0.62-0.67 \\
0.84-0.876\end{array}$ & $\begin{array}{l}1528.2 \\
974.3\end{array}$ & 1 & $\begin{array}{l}\text { 2006-2007, Every } 8 \text { days } \\
\text { Maximum Value Composite } \\
\text { (MVC) }\end{array}$ \\
\hline $\begin{array}{l}\text { 5. MODIS } \\
\text { (MOD09A1) }\end{array}$ & 500 & $36 / 7^{*}$ & 12 & $\begin{array}{l}0.62-0.67 \\
0.84-0.876 \\
0.459-0.479 \\
0.545-0.565 \\
1.23-1.25 \\
1.63-1.65 \\
2.11-2.16\end{array}$ & $\begin{array}{l}1528.2 \\
974.3 \\
2053 \\
1719.8 \\
447.4 \\
227.4 \\
86.7\end{array}$ & 1 & 2006-2007, Every 8 days MVC \\
\hline
\end{tabular}

${ }^{*}$ Modis 500m (Mod09A1) has 36 bands, but we considered only the first 7 


\subsection{Acquisition of images at various resolutions or scales}

Imagery was acquired at 4 distinct spectral, spatial, radiometric, and temporal resolutions (Table 1). The data consisted of very fine resolution 0.61-2.44 meter resolution Quickbird, $23.5 \mathrm{~m}$ IRS Satellite, $250 \mathrm{~m}$ and $500 \mathrm{~m}$ MODIS imagery.

\subsection{Image normalization}

The data acquired from different sensors and even the data acquired from same sensor on different dates need to be normalized before they can be compared. Hence, digital numbers (DNs) were converted to absolute units of radiance ( $\left.\mathrm{W} \mathrm{m}^{-2} \mathrm{sr}^{-1} \mu \mathrm{m}^{-1}\right)$, then to apparent atsatellite reflectance (\%), and finally to surface reflectance (\%) after atmospheric correction [5-6].

\subsubsection{Quickbird DN to Reflectance}

The Radiometric resolution of Quickbird digital number (DN) data is recorded in 11-bit and stored either in 16-bits or down scaled to 8-bits. There were two steps to calculate radiance from $\mathrm{DN}$ values. First is to calculate band integrated radiance expressed as:

$$
L_{\text {Pixel,Band }}=\text { absCalFactor }_{\lambda} * D N_{i j}
$$

Where: $\mathrm{L}_{\text {Pixel, Band }}$ is band integrated radiance, absCalFactor is absolute calibration factor as is 0.064 for Pan band, 0.016 for blue, 0.014 for green, 0.013 for red and 0.015 for NIR. $\mathrm{DN}_{\mathrm{ij}}$ is digital number of pixel in row $\mathrm{i}$ and column $\mathrm{j}$.

The band average radiance can be calculated based on band integrated radiance using equation:

$$
L_{\lambda_{\text {Pixel,Band }}}=\frac{L_{\text {Pixel,Band }}}{\Delta \lambda_{\text {Band }}}
$$

Where:

$L_{\lambda_{\text {Pixel,Band }}}$ is band averaged radiance, $\Delta \lambda_{\text {Band }}$ is effective bandwidth as shown in Table 2.

\begin{tabular}{|c|c|c|}
\hline Spectral Bands & $\begin{array}{l}\text { Effective bandwidth } \\
\text { ( } \Delta \lambda \text { Band }) \\
{[\mu \mathrm{m}]}\end{array}$ & $\begin{array}{l}\text { Spectral Irradiance } \\
\text { (ESUN } \lambda \text { ) } \\
{[\mathrm{W}-\mathbf{m}-2-\mu \mathrm{m}-1]}\end{array}$ \\
\hline Panchromatic & 0.398 & 1381.79 \\
\hline Blue & 0.068 & 1924.59 \\
\hline Green & 0.099 & 1843.08 \\
\hline Red & 0.071 & 1574.77 \\
\hline NIR & 0.114 & 1113.71 \\
\hline
\end{tabular}

Table 2. Quickbird effective bandwidths and band-averaged solar spectral irradiance.

\subsubsection{IRS P6 (Resourcesat-1) DN data to Reflectance}

IRS P6 (Resoursesat-1) Linear Imaging Self Scanning (LISS-3) sensor spectral radiance was computed using the following equation: 


$$
L_{\lambda}=\frac{D N_{i j} \times \text { Gain }}{255}
$$

Where, Gain is radiance gain given in Table 3 . The specific Gain setting was given in individual image header file.

Table 3. Radiance gain values for IRS-P6 image data.

\begin{tabular}{|c|c|c|c|c|c|}
\hline $\begin{array}{l}\text { Gain } \\
\text { Setting }\end{array}$ & Band2 & Band3 & Band4 & \multicolumn{2}{|c|}{$\begin{array}{c}\text { Band5 } \\
T<24^{\circ} \mathrm{C} \quad \mathrm{T}>\mathbf{2 4 ^ { \circ }} \mathrm{C}\end{array}$} \\
\hline G1 & 26.609 & 27.32 & 31.018 & 6.903 & 6.944 \\
\hline G2 & 18.471 & 18.179 & 20.695 & 3.397 & 3.406 \\
\hline G3 & 12.064 & 15.131 & 15.757 & 1.644 & 1.636 \\
\hline G4 & 8.988 & 10.304 & 10.876 & 0.767 & 0.752 \\
\hline
\end{tabular}

\subsubsection{Landsat-7 ETM+DN values to radiance and temperature}

The ETM+ 8-bit DNs were converted to radiances using the equation [7]:

This can also be expressed as:

$$
\mathrm{L} \lambda=\text { gain } * \mathrm{DN}+\text { offset }
$$

$$
L_{\lambda}=\frac{L_{\text {max }}-L_{\text {min }}}{Q C a l_{\text {max }}-Q C a l_{\text {min }}} \times\left(D N-Q C a l_{\text {min }}\right)+L_{\text {min }}
$$

Where, $\mathrm{QCal}_{\min }=1, \mathrm{QCal}_{\max }=225, \mathrm{~L}_{\min }$ and $\mathrm{L}_{\max }$ are the spectral radiances for each band at DN 1 and 255 (i.e. $\mathrm{QCal}_{\min }, \mathrm{QCal}_{\max }$ ), respectively. The $\mathrm{L}_{\min }$ and $\mathrm{L}_{\max }$ values $\left(\mathrm{W} / \mathrm{m}^{2} \mathrm{Sr} \mu \mathrm{m}\right.$ ) are found in image header file.

ETM+ Band 6 imagery can also be converted from spectral radiance (as described above) to a more physically useful variable. This is the effective at-satellite temperatures of the viewed Earth-atmosphere system under an assumption of unity emissivity and using prelaunch calibration constants. The conversion formula is:

$$
T=\frac{K 2}{\operatorname{Ln}(\mathrm{K} 1 / \mathrm{L} \lambda)+1}
$$

Where, $\mathrm{T}$ is effective at-sensor temperature in degree Kelvin, $\mathrm{K} 1$ and $\mathrm{K} 2$ are calibration constants, $\mathrm{K} 1=666.09 \mathrm{Wm}^{-2} \mathrm{sr}^{-1} \mu \mathrm{m}^{-1} ; \mathrm{K} 2=1282.71$ degree Kelvin.

A reduction in between-scene variability can be achieved through normalization for solar irradiance by converting spectral radiance, as calculated above, to planetary reflectance or albedo. This combined surface and atmospheric reflectance of the Earth is computed with the following formula [7]:

$$
\rho_{p}=\frac{\pi L_{\lambda} d^{2}}{E S U N_{\lambda} \times \operatorname{Cos} \theta_{s}}
$$

Where $\rho_{p}$ is the at-satellite exo-atmospheric reflectance (or top of the atmosphere (TOA) reflectance or apparent reflectance in $\%, \mathrm{~L}_{\lambda}$ is the radiance $\left(\mathrm{W} \mathrm{m}^{-2} \mathrm{sr}^{-1} \mu \mathrm{m}^{-1}\right), d$ is the earth sun distance in astronomic units (dimensionless) at the acquisition date [7], $\mathrm{ESUN}_{\lambda}$ is the mean solar exo-atmospheric irradiance $\left(\mathrm{W} \mathrm{m}^{-2} \mathrm{sr}^{-1} \mu \mathrm{m}^{-1}\right)$ or solar flux, and $\theta_{s}$ is solar zenith angle in degrees (i.e., 90 degrees minus the sun elevation or sun angle when the scene is recorded as given in the image header file). 


\subsubsection{MODIS surface reflectance}

MODIS is a key sensor on the Terra (EOS AM-1) satellite. The MODIS Land Science Team provides a suite of standard MODIS data products to users, including the 8-day composite surface reflectance product (MOD09A1). There are forty-six 8-day composites in a year, starting with Julian date of January 1 each year. The MOD09A1 data are organized in tile fashion and freely available to the public from the United States Geological Survey EROS Data Center (http://edc.usgs.gov). The MODIS data has gone through a rigorous atmospheric correction scheme based on the $6 \mathrm{~S}$ radiative transfer code for normalizing molecular scattering, gaseous absorption, and aerosols that affect the top of the atmosphere (TOA) signal [8]. Aerosol effects are known to remain uncorrected even after long compositing periods (e.g., a month) [8], so such effects in 8-day time intervals are significant. MODIS scans the entire Earth's surface every day, acquiring data in 36 spectral bands. Out of the 36 spectral bands, the first 7 bands are used to study vegetation and land surfaces (Table 1).

\subsection{Field-plot data}

Field-plot data was acquired to correspond with the satellite sensor overpass dates (Table 1 and section 3.3). In all, 911 field-plot data points were gathered and the data consisted of parameters such as wet and dry biomass $\left(\mathrm{kg} / \mathrm{m}^{2}\right)$, crop yield $\left(\mathrm{kg} / \mathrm{m}^{2}\right)$, hyperspectral data from field-based Spectroradiometer, irrigation water applied $\left(\mathrm{m}^{3}\right)$, and climate data (Table 4). The number of samples and the distribution of the field-plot data points for various crops are also shown in Table 4. The spatial distribution of some of the field-plot data points are illustrated in Fig. 2.

\subsubsection{Field experimental sites}

Data from the test sites (fields) at different farms (Water User Association-WUA) were gathered for approximately every 15 -days interval for the five crops: cotton, wheat, rice, and maize. A total of 911 sample points were chosen for four crops: cotton (580), wheat (175), maize (113), and rice paddy (43). Enough care was taken while selecting the locations of the field trials (replications) to represent field-field variability. Distribution of these points over a cropping season was illustrated for one farm at three distinct resolutions in Fig. 2.

Biophysical parameters were collected throughout the crop growing season and includes Leaf Area Index (LAI) (Fig. 3a), biomass (Fig. 3b), spectral measurements (Fig. 4), and yield (Fig. 6a). The meteorological data includes temperature, relative humidity, vapor pressure, sunshine hours, wind speed, rainfall, and evapotranspiration (ET) from an ET gauge. The meteorological data were collected from the digital weather station installed in the field, as well from two government managed weather stations. Table 4 gives an overview of the data collected.

The time-series average Normalized Difference Vegetation Index (NDVI), dry biomass, and LAI for all the fields and points are plotted together indicates a closer comparable seasonal pattern (Fig. 3). The initial emergence of the plant after 45 days (i.e. till the day 173) indicates a slow growth and low canopy cover. The NDVI and LAI curves steepen from day 173 and reach a peak by day 214, representing the maximum vegetative growth. LAI tends to fall earlier than NDVI (Fig. 3a) and NDVI continues to increase at the peak when LAI saturates and /or leaf senescence begins while NDVI also starts falling soon after the senescence and leaf falling starts at lower canopy. The study shows strong relationship between NDVI and LAI which is supported by previous studies [9-12). Dry biomass peaks about 40 days after LAI (Fig. 3b). The seasonal spectrums of the crops were also observed using Spectroradiometer. Initial observations indicate a strong relationship between the crop growth stage (moisture, biomass and vigor) and absorption around $970 \mathrm{~nm}$ (Fig. 4). 
Table 4. Field-plot data collected from field sites. The total sample points collected are 911, of which the crop wise distributions consist of cotton (580), wheat (175), Maize (113) and rice (43).

\begin{tabular}{|c|c|c|c|c|}
\hline Variable & $\begin{array}{l}\text { Temporal } \\
\text { basis } \\
\text { (days) }\end{array}$ & $\begin{array}{l}\text { Spatial } \\
\text { scale }\end{array}$ & $\begin{array}{l}\text { Mean } \\
\text { Sample } \\
\text { size }\end{array}$ & Method \\
\hline Wet biomass $\left(\mathrm{kg} / \mathrm{m}^{2}\right)$ & 15 days & $1 \mathrm{~m}^{2}$ & 224 & Crop cutting \\
\hline Dry biomass $\left(\mathrm{kg} / \mathrm{m}^{2}\right)$ & 15 days & $1 \mathrm{~m}^{2}$ & 224 & Crop cutting \\
\hline Plant Height (mm) & 15 days & $1 \mathrm{~m}^{2}$ & 224 & Ruler \\
\hline Yield $\left(\mathrm{kg} / \mathrm{m}^{2}\right)$ & One time & $1 \mathrm{~m}^{2}$ & 30 & Crop cutting \\
\hline Field NDVI (ratio) & 15 days & $1 \mathrm{~m}^{2}$ & 220 & NDVI Camera \\
\hline LAI $\left(\mathrm{m}^{2} / \mathrm{m}^{2}\right)$ & 15 days & $1 \mathrm{~m}^{2}$ & 224 & LAI Meter \\
\hline $\begin{array}{l}\text { Canopy reflectance } \\
(\%)\end{array}$ & 15 days & Point & 224 & ASD Spectroradiometer \\
\hline Irrigation & $\begin{array}{l}\text { Each } \\
\text { application }\end{array}$ & Field & 4 & Weirs /V-notches \\
\hline $\begin{array}{l}\text { Climate data (Temp., } \\
\text { RH., Wind, Rain, } \\
\text { Radiation) }\end{array}$ & $30 \mathrm{~min}$ & $\mathrm{~km}^{2}$ & 1 & $\begin{array}{l}\text { Meteorological station and } \\
\text { digital weather stations }\end{array}$ \\
\hline
\end{tabular}

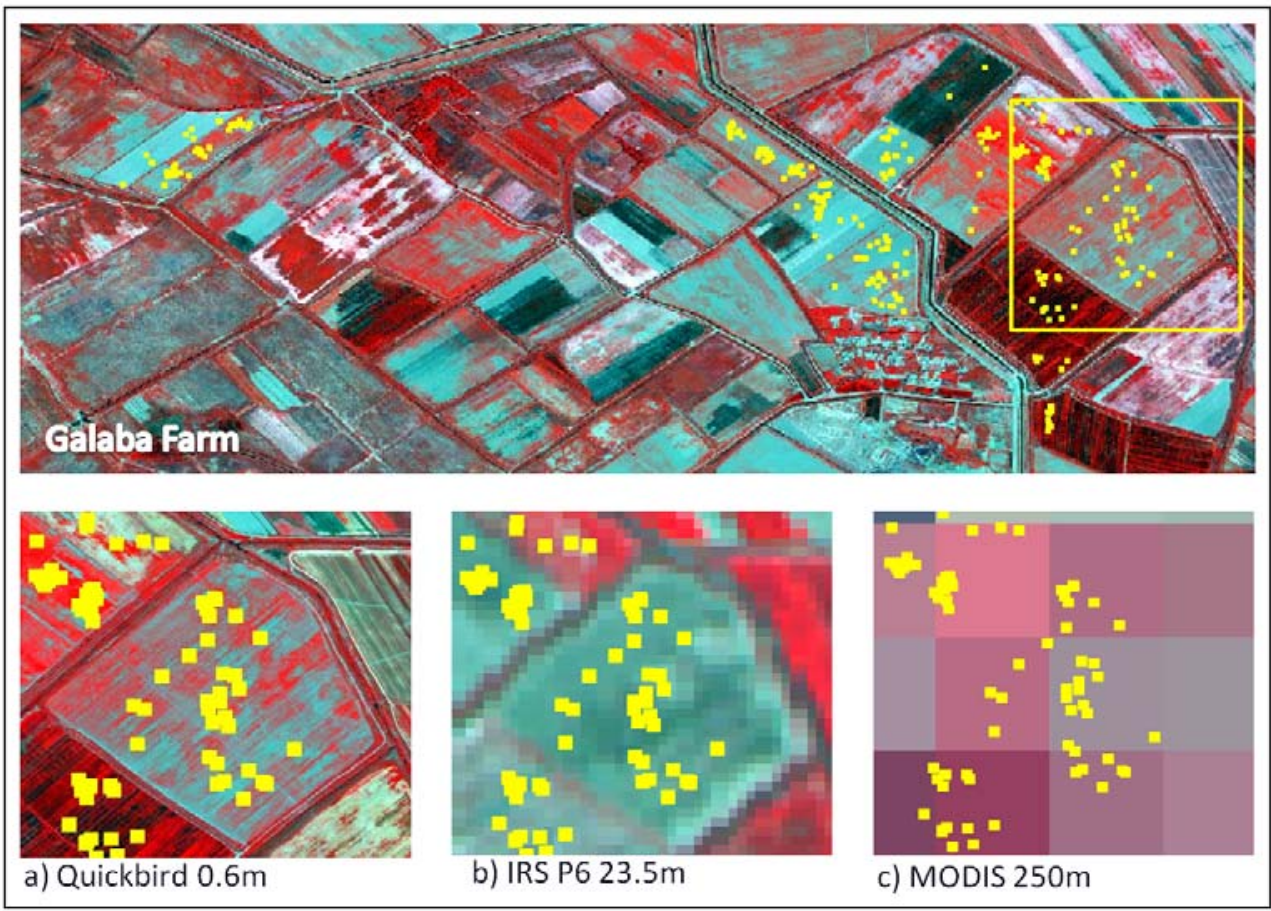

Fig. 2. Spatial distribution of the field-plot data points in the study area. The spatial distribution of the field-plot data points were shown for: (a) Quickbird, (b) IRS, and (c) MODIS 250-m. 


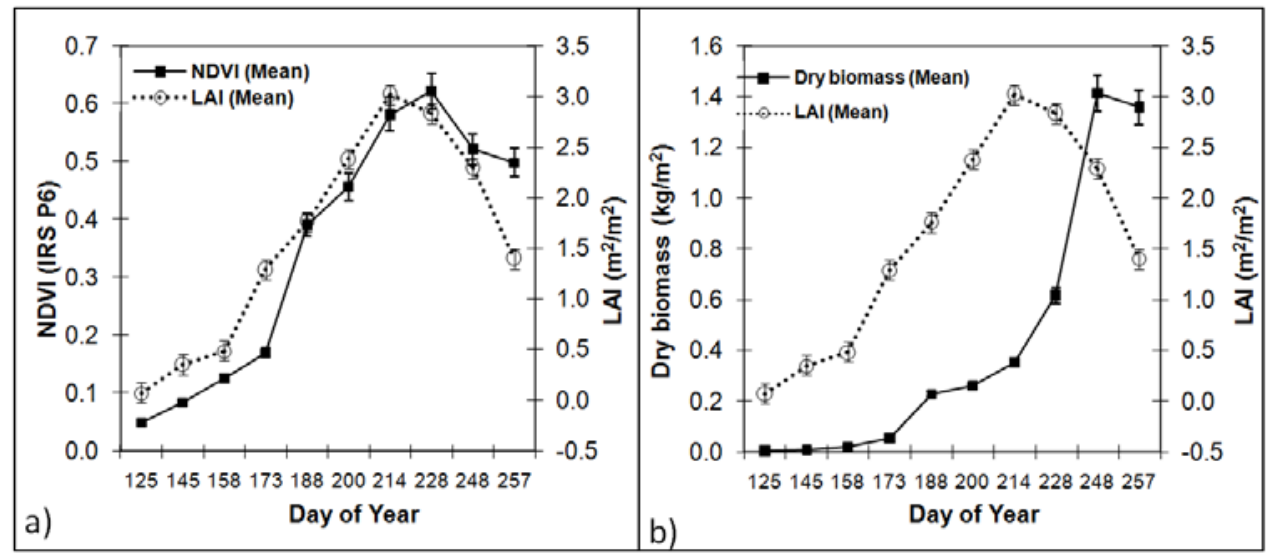

Fig. 3. Seasonal relationship between LAI and NDVI (a) and LAI and Dry biomass (b) plotted for the average values derived from all field points collected during 11 visits roughly at 15 days interval.

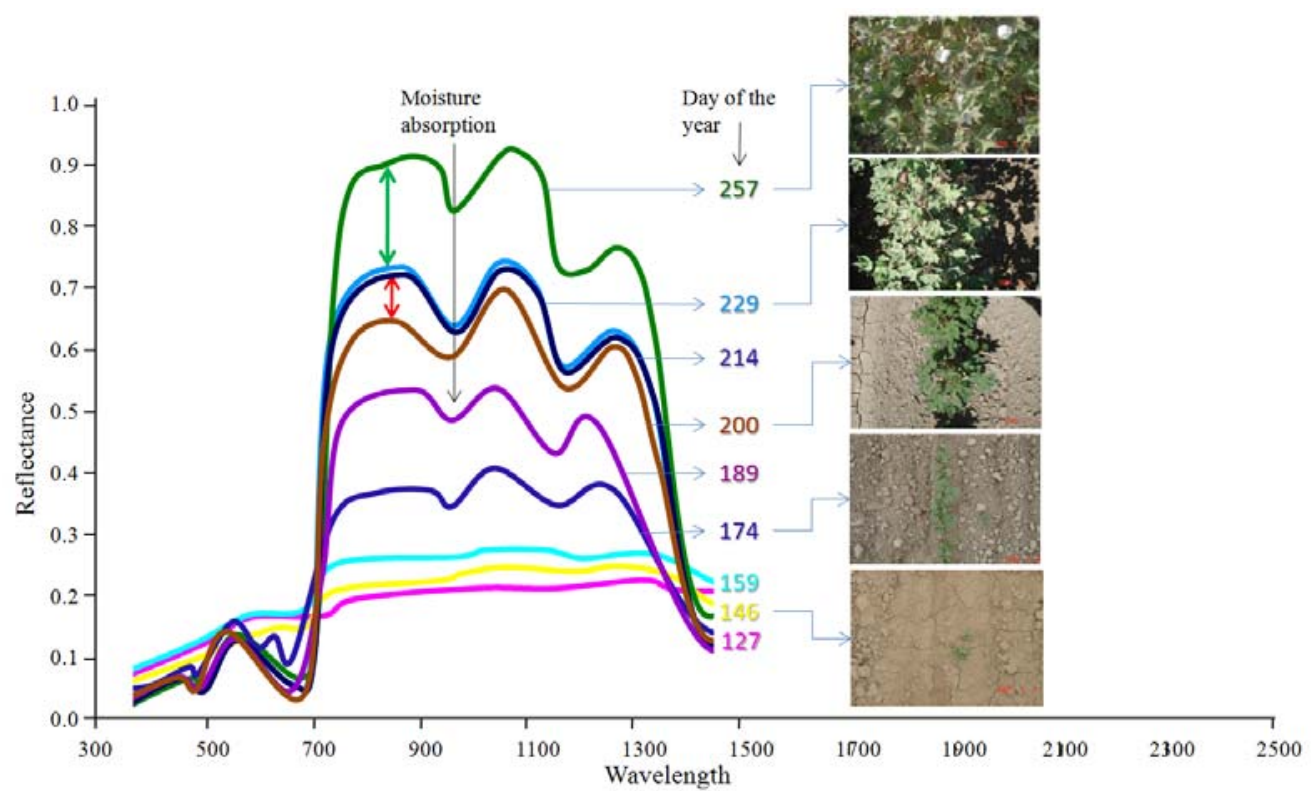

Fig. 4. Seasonal vegetation spectra of a cotton field measured roughly at 15 day intervals and some photographs of the corresponding biomass growth.

\section{WATER PRODUCTIVITY MAPPING}

The three major steps involved in the mapping process were in producing:

a) Crop productivity maps (CPMs; $\mathrm{kg} / \mathrm{m}^{2}$ or $\left.\mathrm{kg} / \mathrm{pixel}\right)$, which involves;

i. Crop type mapping;

ii. Spectro-biophysical/yield modeling; and

iii. Extrapolating the best spectro-biophysical/yield modeling to larger areas using remotely sensed data. 
b) Water use (actual ET) maps (WUMs; $\mathrm{m}^{3} / \mathrm{m}^{2}$ or $\mathrm{m}^{3} /$ pixel)

iv. Deriving water use maps (or actual ET) through simplified surface energy balance (SSEB) model; and

c) Water productivity maps (WPMs; $\mathbf{k g} / \mathrm{m}^{3}$ )

v. Producing water productivity maps by dividing CPMs with WUMs.

\subsection{Crop productivity mapping ( $\mathrm{kg} / \mathrm{m} 2$ or $\mathrm{kg} / \mathrm{pixel})$}

The crop productivity maps (CPMs) were produced in three steps:

\subsubsection{Mapping crop types using remote sensing}

It is important to produce water productivity maps (WPMs) that are crop specific. As every crop type has different water needs to produce a kilogram of marketable produce, it is important to delineate and map crop types first. This allows the development of crop specific spectro-biophysical models (section 4.2), which in turn allow assessment of inter- and intrafield variability in land and water productivity.

Crop types were mapped using time-series IRS-P6 data and the single date Quickbird data. Unsupervised classification of the IRS data, and class identification and labeling process $[13,14]$, were used to delineate and map crop types. IRS-P6 and Quickbird offers detailed within-field variability and clearly demarcates the field boundaries of a crop. In order to define clear field boundaries at other resolutions, the crop and field boundaries were digitized manually from the Quickbird imagery. Due to their distinct cropping calendars, all four crops were easily distinguishable.

\subsubsection{Spectro-biophysical/yield models}

The crop biophysical and yield variables were related to spectral measurements from space. The most commonly used crop variables establishing such relations were the leaf area index (LAI), Wet Biomass (WBM), Dry Biomass (DBM), and grain Yield (YLD). Variation in the reflectance was normally associated with chlorophyll and water contents of the plants [1516]. Satellite-based radiative indices were good indicator of LAI, which is one of the important parameters in the models. Some were also correlated with photosynthetically active radiation (PAR), which is correlated to the $\mathrm{CO}_{2}$ assimilation [17]. LAI, biomass, and, to some extent, plant height were excellent indicators of the plant growth, condition, and yield [18]. The spectral vegetation indices derived using field-plot data and space-borne sensors were effectively used for rapid assessment and characterization of crop biophysical variables such as biomass, LAI, plant height, and yield [11,19-22]. A Production Efficiency Model (PEM) that estimates crop growth from intercepted photosynthetically active radiation (IPAR) and light use efficiency $(\varepsilon)$ was introduced $[23,24]$. Subsequent studies further improved the model by making ' $\varepsilon$ ' a function of temperature, water, and nutrient stress, such as the Carnegie-Ames-Stanford-Approach (CASA) [25-26]. The methodology has been widely used to estimate terrestrial ecosystem net primary production (NPP), global carbon cycle [25-27), and crop production at regional scale [28-30].

During this research, extensive measurements of LAI, biomass and yield were collected during routine field visit at every $\sim 15$ days interval (Table 4). These measurements were related to wavebands and indices derived from the satellite sensor data (Table 1). In the past, remote sensing has proved very useful in estimating area and production of cereals and other food crops $[6,12,31]$ and the relationships have improved with the use of modern highspectral and high-spatial sensors $[5,12]$. For example, the NDVI was found to correlate with net primary production, biomass, vegetation fraction, and yield [32-37]. Although the results of correlation analysis are purely empirical, they are in agreement with numerous theoretical, experimental, and statistical studies [39]. In this research, spectro-biophysical models were 
run using statistical analysis system (SAS) software package. Biophysical and yield data (Table 2) gathered during routine field visits were related to spectral data obtained from various sensors (Table 1). The type of models included: (a) linear, (b) multiple linear, (c) nonlinear power, and (d) non-linear exponential.

\subsubsection{Extrapolation of models to spatial domain}

One of the biggest strengths of remote sensing lies in the observation of the entire landscape rather than just few points [40]. With good understanding of the relationships between crop variables and spectral reflectivity and/or indices it is possible to extrapolate the understanding gained through models to larger areas by utilizing the best models of specific crops and specific variables (developed in section 4.1.2) to specific crops (delineated in section 4.1.1).

Extrapolation, for example, will involve taking the best cotton yield predictor model developed in section 4.1.2 based on point data and applying the same to all cotton growing areas that has been delineated using the remotely sensed data.

\subsection{Mapping Evapotranspiration}

Water used by crops was determined by computing actual evapotranspiration $\left(\mathrm{ET}_{\text {actual }}\right)$ from remote sensing and non-remote sensing approaches. The ET derived from different surfaces varies with different methods $[41,42,43]$, which leads to inconsistency and uncertainty in ET estimation. The Food and Agriculture Organization (FAO) Penman-Monteith equation - with the parameterization as elaborated by Allen et al. (44) has become the de facto standard method to estimate reference ET (45) for point-level ET estimation using climate data collected at field scale. The point based ET measurements from the field and weather stations data have been integrated with remote sensing images to spatially extrapolate from pixel level to basin scale [46;47].

However, the water used by crops is best determined using surface energy balance algorithms that are primarily dependant on remotely sensed data. The potential of remote sensing in estimating the ET [48-51] is well established using Surface Energy Balance Algorithm (SEBAL) [52-53], the modified SEBAL, and mapping ET with high resolution and internalized calibration (METRIC) [54]. Gabriel and Verdin [55-56] and Gabriel et al [57] recommended a Simplified Surface Energy Balance (SSEB) model using remote sensing. The SSEB approach was adopted in this study to facilitate rapid computation of water use over large areas in a rapid time-frame. The SSEB model is defined as follows:

$$
\mathrm{ET}_{\text {actual }}\left(\mathrm{m}^{3} / \mathrm{m}^{2} \text { or } \mathrm{m}^{3} / \text { pixel }\right)=\mathrm{ET}_{\text {fraction }} * \mathrm{ET}_{\text {reference }}
$$

Water used by crops, the ET (expressed in $\mathrm{m}^{3} / \mathrm{ha}$ or $\mathrm{mm} / \mathrm{m}^{2}$ ) was determined from remote sensing by calculating the ETactual based on the following steps:

ETfraction from Landsat7 ETM+ thermal data. The principal assumption in SSEB model that the latent heat flux $\left(\mathrm{ET}_{\text {actual }}\right)$ varies linearly between the "hot" and "cold" pixels. The fraction of ET was estimated from the land surface temperature (LST) of "hot" and "cold" pixels using following formula:

$$
\text { ETfraction }=(\text { Thot }-\mathrm{T}) /(\text { Thot }- \text { Tcold })
$$

Where: ETfraction was the fraction of ET; T is the LST of any pixel; Thot and Tcold are the LST of "hot" and "cold" pixels respectively, selected inside the study area. The $\mathrm{ET}_{\text {reference }}$ was calculated from weather station data using Penman-Monteith equation [44]. The final ET value for each pixel was determined by multiplying ETfraction with ETreference, which finally gives ETactual. 


\subsection{Water productivity mapping}

\subsubsection{Producing water productivity maps (WPMs)}

The WPMs were produced by dividing the crop productivity map (CPMs; section 4.1) with water use map (WUMs; section 4.2). The WPMs were defined as:

Water Productivity Maps $\left(\mathrm{kg} / \mathrm{m}^{3}\right)=\frac{\text { Yield }\left(\mathrm{kg} / \mathrm{m}^{2} \text { or } \mathrm{kg} / \mathrm{pixel}\right) \text { or economic value }(\$)}{\text { Water use }\left(\mathrm{m}^{3} / \mathrm{m}^{2}{\left.\text { or } \mathrm{m}^{3} / \text { pixel }\right)}\right)}$

\section{RESULTS AND DISCUSSIONS}

\subsection{Crop productivity mapping}

\subsubsection{Crop type maps at various resolutions}

The results of the attempts to map the crop type maps using remotely sensed data at 4 spatial resolutions, Quickbird (2.4m), IRS P6 (23.5m), and MODIS 250m $\backslash 500 \mathrm{~m}$ MOD09Q1, are shown in Fig. 5. It was possible to delineate crop types using the Quickbird (Fig. 5a) and IRS (Fig. 5b) data. At 250m resolution (MODIS) it is only possible to establish the dominant crop in the mix (Fig. 5c). Using the MODIS 500m data, only irrigated areas were mapped, without separating any crop types or crop dominance (Fig. 5d). The ability of satellite sensor data to map crop types and/or their dominance at 4 spatial resolutions is summarized in Table 5.

Table 5. The ability to map irrigated crop types and their dominance using satellite sensor data at 4 spatial resolutions.

\begin{tabular}{|c|c|c|c|c|c|}
\hline $\begin{array}{l}\text { Aggregated } \\
\text { types }\end{array}$ & LULC & $\begin{array}{l}\text { Quickbird } \\
(2.4 \mathrm{~m})\end{array}$ & $\begin{array}{l}\text { IRS-P6 } \\
(23.5 \mathrm{~m})\end{array}$ & $\begin{array}{l}\text { MODIS } \\
(\mathbf{2 5 0 m})\end{array}$ & $\begin{array}{l}\text { MODIS } \\
(\mathbf{5 0 0 m})\end{array}$ \\
\hline Cotton & & Yes & Yes & zero & zero \\
\hline Wheat & & Yes & Yes & zero & zero \\
\hline Rice paddy & & Yes & Yes & zero & zero \\
\hline Cotton dominant & & Yes & Yes & Yes & zero \\
\hline Rice dominant & & Yes & Yes & Yes & zero \\
\hline
\end{tabular}

\subsubsection{Modeling crop growth and yield (Spectro-biophysicallyield models)}

The spectro-biophysical/yield models were developed using Quickbird and IRS-P6 data for cotton, wheat, and maize (Table 6). The crop variables modeled were wet and dry biomass $(\mathrm{kg} / \mathrm{m} 2)$, LAI ( $\mathrm{m} 2 / \mathrm{m} 2)$, and grain yield (ton/ha). The best models to determine variables such as biomass, LAI, and yield were highly significant and explained around 80 percent variability for IRS-P6 and 70 percent variability for Quickbird data. Due to the non availability of time-series images, Quickbird models were only used for biomass. Most of the variables were modeled with IRS-P6 data due to good temporal coverage for entire growing season. The best IRS-based models for cotton were the wet biomass, dry biomass, LAI, and yield with 72-83 percent variability (Table 6). The best fit models for the wheat and maize are the LAI, wet biomass, and yield (Table 6). Spectro-biophysical/yield models could not be developed from MODIS data due to its inability to separate crop types. 


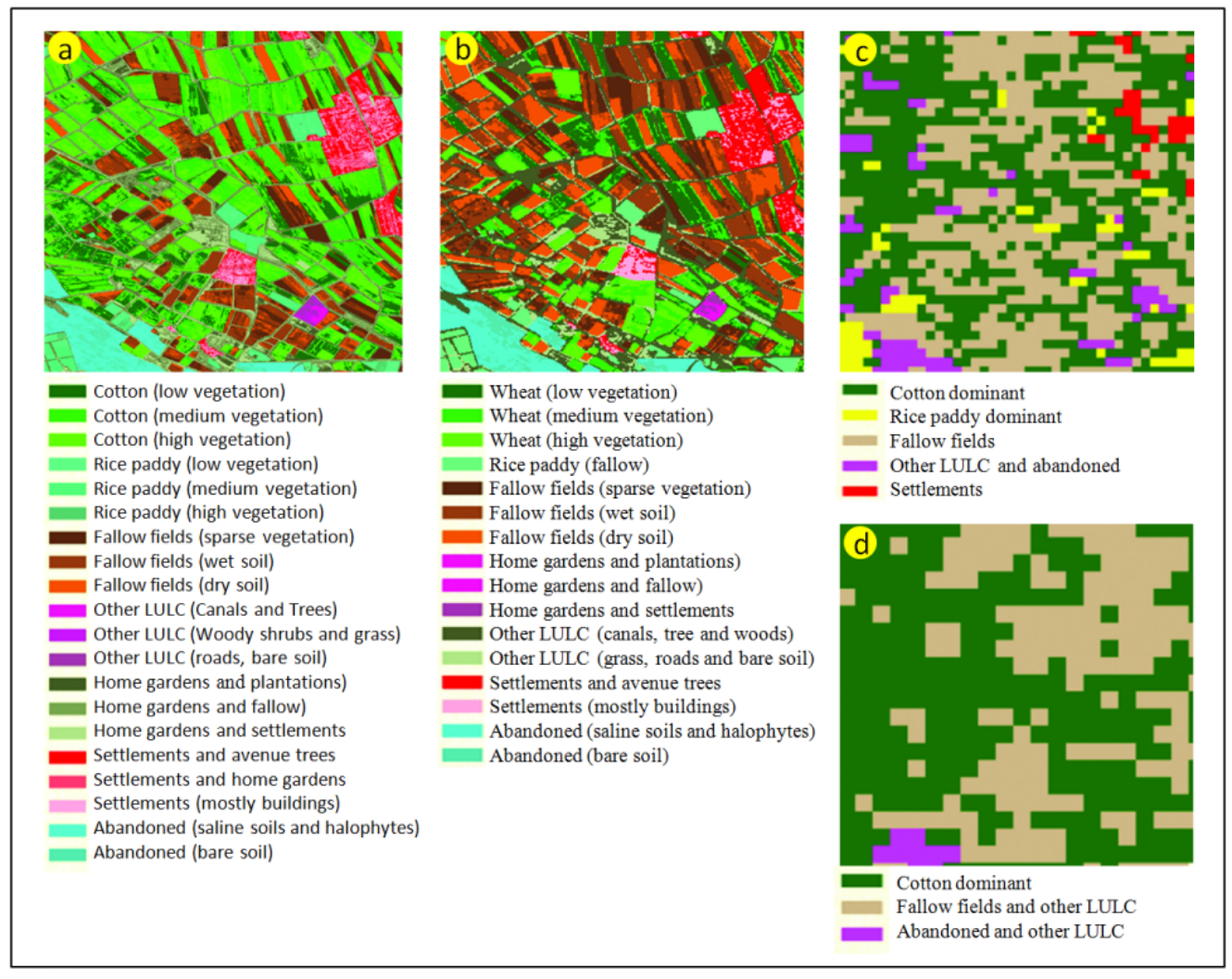

Fig. 5. Crop types mapped at various resolutions. Crop types mapped using: (a) Quickbird 2.4m, (b) IRS P6 (Resoursesat1, Liss3) 23.5m, (c) MODIS 250m, and (d) MODIS 500m. The classification schemes clearly indicate that the number of classes reduced with increasing pixel size due to aggregation.

Table 6. The best spectro-biophysical/yield models using Quickbird $2.44 \mathrm{~m}$ and IRS $23.5 \mathrm{~m}$ data.

\begin{tabular}{lllll}
\hline Sensor & Crop & Variable & Equation & $\boldsymbol{r}^{2}$ \\
\hline IRS & Cotton & Wet biomass & $\mathrm{y}=71.18^{*}(\mathrm{x})^{3.96}$ & 0.83 \\
& & Dry biomass & $\mathrm{y}=51.59^{*}(\mathrm{x})^{4.86}$ & 0.82 \\
& & LAI & $\mathrm{y}=10.37^{*}(\mathrm{x})^{1.916}$ & 0.73 \\
& & Yield & $\mathrm{y}=5.156^{*} \mathrm{x}-0.964$ & 0.75 \\
IRS & \multirow{2}{*}{ Wheat } & LAI & $\mathrm{y}=0.005^{*}(\mathrm{x})^{2}-0.509^{*}(\mathrm{x})+7.175$ & 0.80 \\
& & Yield & $\mathrm{y}=6.192^{*} \mathrm{x}-0.47$ & 0.66 \\
$\mathrm{IRS}$ & Maize & Wet biomass & $\mathrm{y}=34.664^{*}(\mathrm{x})^{4.196}$ & 0.87 \\
\hline
\end{tabular}

Note; $x=$ NDVI

\subsubsection{Extrapolation of models to spatial domain and deriving crop productivity maps (CPMs)}

The best models (Table 6) were used on the relevant images (see image list in Table 1) to extrapolate and derive crop characteristics such as grain yield, wet biomass, dry biomass, and LAI. The result of extrapolation was shown for cotton yield (ton/ha) using IRS data (Fig. 7). The extrapolation was possible as a result of the good understanding we had through model development (Table 4) and delineation of crop types (section 4.1.1 and 5.1.1). The extrapolated areas (Fig. 7) show spatial variability within a crop derived for various crop 
variables. These CPMs were one of the key parameter in understanding within and betweenfield variability leading to finding appropriate site specific solutions.

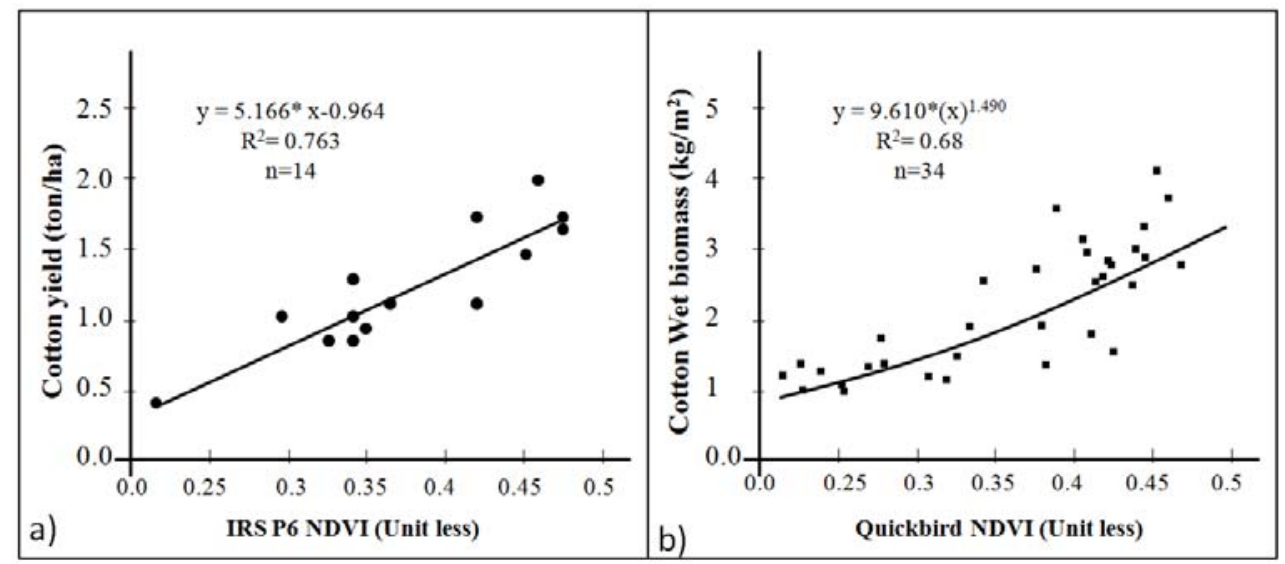

Fig. 6. The relationship between spectral and biophysical variables for the spaceborne satellite sensors data and field-plot data illustrated taking: (a) cotton yield versus IRS P6 NDVI and (b) cotton wet biomass versus Quickbird NDVI.

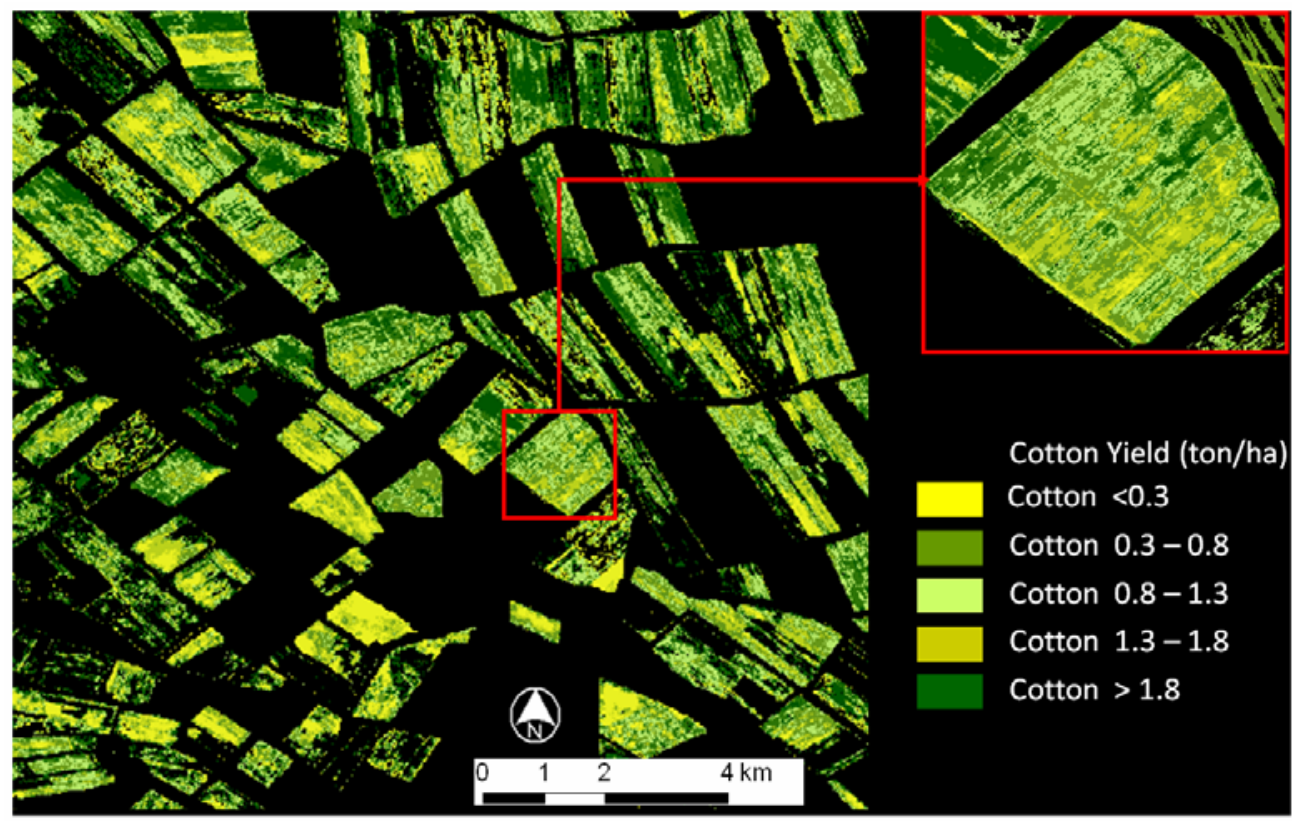

Fig. 7. Crop productivity map (CPM). CPM illustrated using a IRS P6 image by extrapolation of the best crop specific spectro-biophysical/yield models and by using crop type maps (Fig.5).

\subsection{Water use (actual ET) mapping (m3/m2 or m3/pixel)}

The water use by crops was determined by $\mathrm{ET}_{\text {actual }}$ computations. The simplified surface energy balance (SSEB) model algorithm was used to determine $\mathrm{ET}_{\text {actual. }}$. First, it required computation of evaporative fraction, which was then multiplied by $\mathrm{ET}_{\text {reference }}$ to obtain the $\mathrm{ET}_{\text {actual. }}$. 
The evaporative fraction $\left(\mathrm{ET}_{\text {fraction }}\right)$ was determined using the Landsat-7 ETM+ thermal imagery. $\mathrm{ET}_{\text {reference }}$ was computed using FAO Penman-Monteith formula. The $\mathrm{ET}_{\text {actual }}$ was then computed by multiplying $\mathrm{ET}_{\text {fraction }} * \mathrm{ET}_{\text {reference }}$ and was computed for every month. Monthly $\mathrm{ET}_{\text {actual, }}$ were then cumulated, taking the cropping calendar into consideration. This lead to an accumulated $\mathrm{ET}_{\text {actual, }}$ for the entire crop growing season (see an example for cotton crop in Fig. 8).

\subsubsection{Relationship between ETactual versus NDVI}

The NDVI showed strong relationship with $\mathrm{ET}_{\text {actual }}$ derived from Landsat-7 ETM+ and climate data using SSEB model (Fig. 9). We have presented this relationship to show potential of vegetation indices in mapping ET. The approach requires more research for individual crops and by using larger sample size of data.

The IRS P6 derived NDVI values of the cotton crop were correlated with ETfraction from ETM+ images. Platonov et al. [59] have reported similar agreement when compared Landsat-7 ETM+ NDVI values with Landsat-7 ETM+ derived ET $_{\text {fraction. The daily water }}$ consumption by field crops were calculated by multiplying ETreference with ETfraction with an assumption that ETfraction derived for the day for which the image was acquired remains constant throughout the month for a given crop. Second, crop wise water use per pixel was determined on monthly basis leads to entire growing season. The results are finally presented in thousands $\mathrm{m}^{3} /$ ha of water used for the entire study area.

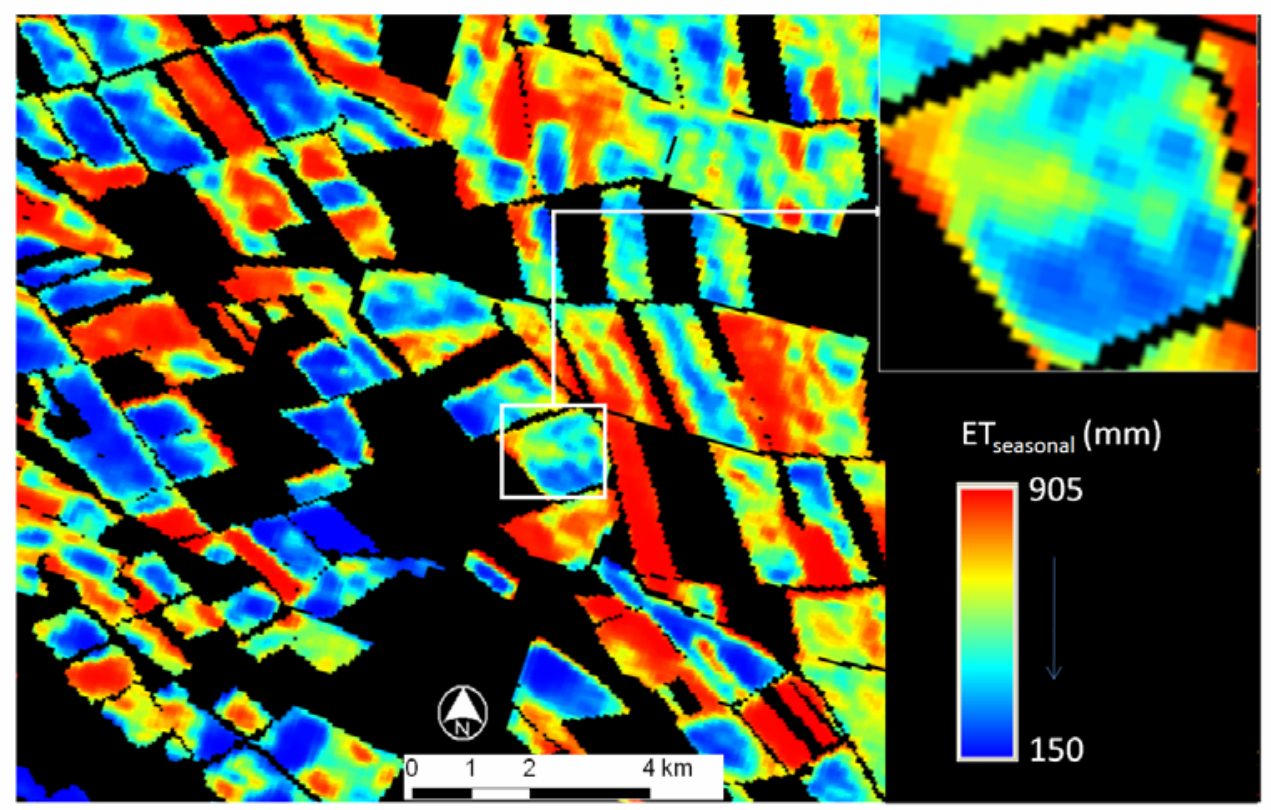

Fig. 8. Water use maps (WUMs). WUMs or $\mathrm{ET}_{\text {actual }}$ of cotton crop for the entire crop growing season.

\subsection{Water productivity maps (WPMs)}

Finally, water productivity maps were produced for every crop by dividing the crop productivity maps (CPMs; section 5.1) with water use maps (WUMs; section 5.2). The WPMs produced separately for each crop were put together and presented in Fig. 11.

The water productivity (WP; kilogram of yield per $\mathrm{m}^{3}$ of water delivered or $\mathrm{kg} / \mathrm{m}^{3}$ or economic value, $\$ / \mathrm{m}^{3}$ ) computed using remote sensing for three crops were presented in Table 7. From the results, wheat has the best physical WP, followed by rice, and cotton. 
However, this pattern is reversed when considered in terms of economic value rather than yield by weight as numerator. Cotton then ranks first with an average market value of $\$$ $0.5 / \mathrm{m}^{3}$, followed by wheat, and rice of $\$ 0.3 / \mathrm{m}^{3}$, and $0.1 / \mathrm{m}^{3}$ respectively. The water productivity map for the cotton crop was produced with varying field variability (Fig. 10). An overwhelming proportion cotton fields were under low WP with only about $12 \%$ area in high WP.

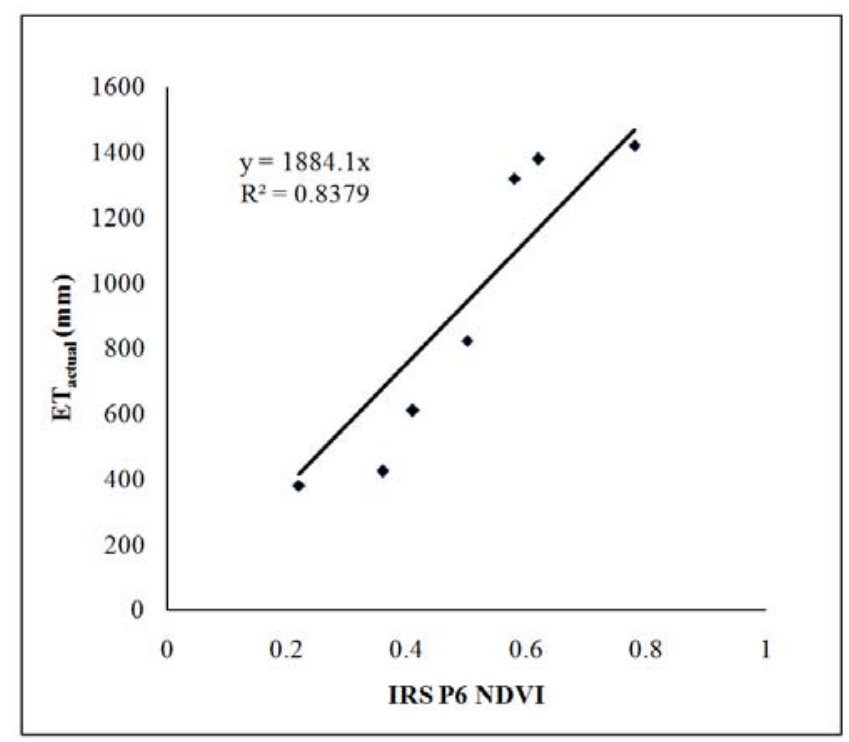

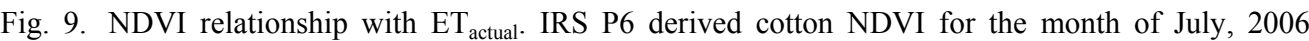
compared with $\mathrm{ET}_{\text {actual }}$ derived using SSEB model from the Landsat7 ETM+ for the July, 2006.

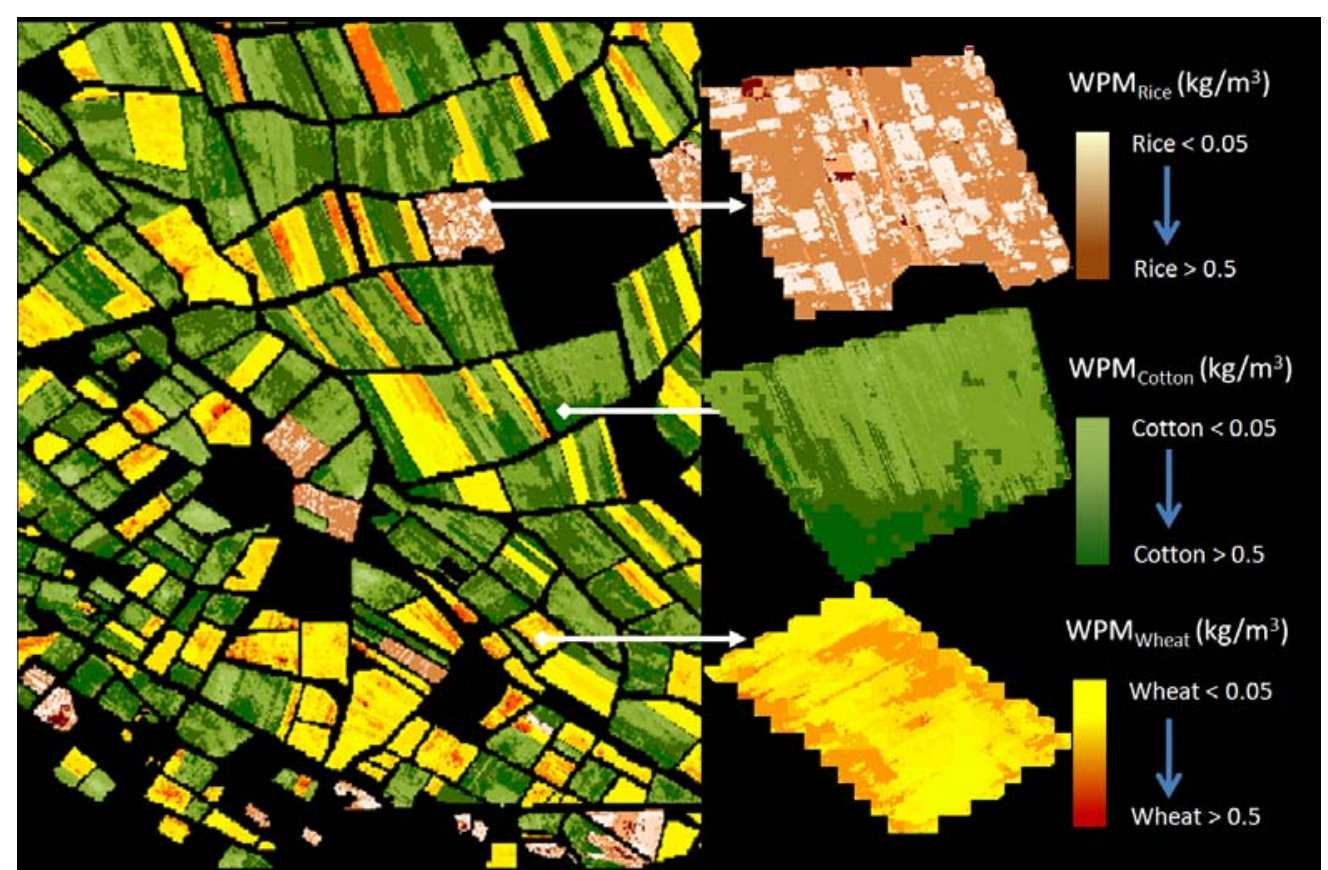

Fig. 10. Water productivity map (WPMs) for 3 crops using IRS P6 data. Overwhelming proportion $(50 \%+)$ of all 3 crops were under low WP, with only about $10 \%$ area in high WP. 
Table 7. Water productivity of the three selected crops determined using IRS P6 and field-plot data.

\begin{tabular}{|c|c|c|c|c|c|}
\hline Crop type & $\begin{array}{c}\text { Area } \\
\text { (ha) }\end{array}$ & $\begin{array}{c}\text { Seasonal } \\
\text { Crop } \\
\mathbf{E T}_{\text {actual }} \\
\left(\mathbf{m}^{3} / \mathbf{h a}\right)\end{array}$ & $\begin{array}{c}\text { Grain } \\
\text { Yield } \\
\text { (kg/ha) }\end{array}$ & $\begin{array}{c}\text { Water } \\
\text { Productivity } \\
\text { based on } \\
\text { ET }_{\text {actual }}\left(\mathbf{k g} / \mathrm{m}^{3}\right)\end{array}$ & $\begin{array}{l}\text { Water Productivity } \\
\text { based on average } \\
\text { market value in Asia } \\
\left(\$ / \mathbf{m}^{3}\right)\end{array}$ \\
\hline Cotton & 3783 & 3050 & 1275 & 0.42 & 0.50 \\
\hline Wheat & 1571 & 3100 & 1850 & 0.60 & 0.33 \\
\hline Rice paddy & 313 & 6650 & 3320 & 0.50 & 0.10 \\
\hline
\end{tabular}

\section{CONCLUSIONS}

This paper demonstrated methods and protocols required for producing water productivity maps using remote sensing data at various resolutions (or scale): (a) Quickbird $2.44 \mathrm{~m}$, (b) IRS $23.5 \mathrm{~m}$, (c) Landsat7 ETM+ thermal data, (d) MODIS 250m data, and (e) MODIS 500m data.

First, crop productivity maps (CPMs; $\mathrm{kg} / \mathrm{m}^{2}$ or $\mathrm{kg} / \mathrm{pixel}$ ) were computed and involved: (i) crop type mapping using remote sensing, (ii) spectro-biophysicallyield modeling involving parameters measured in the field and relating them to spectral wavebands and indices, and (iii) extrapolation of models to larger spatial domains using remote sensing. Crop types were successfully separated by Quickbird and IRS data, but not by MODIS $250 \mathrm{~m}$ or $500 \mathrm{~m}$ data. But it was possible, at times, to map crop dominance using MODIS250m and irrigated crops using MODIS 500m data.

Second, water use maps (WUMs; $\mathrm{m}^{3} / \mathrm{m}^{2}$ ) were determined through thermal data of Landsat-7 ETM+ using simplified surface energy balance (SSEB) model and summing up water use determined from time-series imagery. Results showed that, water use of cotton crop was $3050 \mathrm{~m}^{3} /$ ha whereas wheat used $3100 \mathrm{~m}^{3} / \mathrm{ha}$, and rice $6650 \mathrm{~m}^{3} / \mathrm{ha}$.

Third, water productivity maps (WPMs) were produced by dividing crop productivity maps with water use maps. Wheat with $0.60 \mathrm{~kg} / \mathrm{m}^{3}$ had the best water productivity (WP), followed by rice with $0.5 \mathrm{~kg} / \mathrm{m}^{3}$, and cotton with $0.42 \mathrm{~kg} / \mathrm{m}^{3}$. In terms of economic value of WP, cotton crop earned about the $\$ 0.5 / \mathrm{m}^{3}$ followed by wheat with $\$ 0.33 / \mathrm{m}^{3}$, and rice with $\$$ $0.10 / \mathrm{m}^{3}$. The study has successfully delineated the areas of low and high WP for 3 crops (Figure 10). An overwhelming proportion $(50 \%+)$ of the irrigated areas were under low WP with only about $10 \%$ area in high WP. These results imply that there is significant scope for increasing WP for growing more food to feed the ballooning populations in the coming decades without having to increase allocations of croplands andlor water.

\section{Acknowledgements}

The authors would like to thank Prof. Frank Rijsberman, Director of Water and Climate Adaptation Initiatives, Google.org (formerly Director General of IWMI) for the support and encouragement for this project. The funding for the proposal came from European Union funds for the International Water Management Institute (IWMI). The funding also involved IWMI's core funds. The Drs. Xiao and Biradar were also supported by the grants from NASA Land Use and Land Cover Change program. The field research work in this paper was conducted when first two authors were with IWMI, authors would like thank two field researchers Mr. Shavkat and Mr. Sabir Jan for their excellent help in field data collection. 


\section{References}

[1] S. Postel, "Water and Agriculture" in Water in Crisis: A Guide to the World's Fresh Water Resources, P. H. Gleick, Ed., pp. 56-66 Oxford University Press, Oxford (1993).

[2] W.G.M. Bastiaanssen, T. Thiruvengadachari, R. Sakthivadivel and D.J. Molden. "Satellite remote sensing for estimating productivities of land and water," Int. Water Res. Dev. 15, 181-196 (1999) [doi:10.1080/07900629949005].

[3] D. J. Molden, "Accounting for water use and productivity," SWIM Paper 1, IWMI, Colombo, 1-16 (1997).

[4] P. Raskin, E. Hansen, Z. Zhu, and D. Stavisky. "Simulation of water supply and demand in the Aral Sea Region," Water Int. 17, 55-67 (1992).

[5] P.S. Thenkabail, R.B. Smith, and E. De-Pauw, "Evaluation of Narrowband and Broadband Vegetation Indices for Determining Optimal Hyperspectral Wavebands for Agricultural Crop Characterization," Photogram. Engin Rem. Sens. 68 (6), 607621 (2002).

[6] P.S.Thenkabail, E.A. Enclona, M.S. Ashton, C. Legg, M. Jean De Dieu, "Hyperion, IKONOS, ALI, and ETM+ sensors in the study of African rainforests," Rem. Sens. Environ. 90, 23-43 (2004) [doi:10.1016/j.rse.2003.11.018].

[7] B.L. Markham, and J.L. Barker, "Radiometric properties of U.S. processed Landsat MSS data", Rem. Sens. Environ. 22, 39- 71 (1987) [doi:10.1016/00344257(87)90027-7].

[8] E.F. Vermote, N. El Saleous, and C. Justice, "Atmospheric correction of the MODIS data in the visible to middle infrared: First results," Rem. Sen. Environ. 83, 97-111 (2002) [doi:10.1016/S0034-4257(02)00089-5].

[9] C. L. Wiegand, A. J. Richardson, and E. T. Kanemasu, "Leaf area index estimates for wheat from Landsat and their implications for evapotranspiration and crop modeling", Agron. J. 71,336-342 (1979).

[10] C. J. Tucker, "Red and photographic infrared linear combinations for monitoring vegetation," Rem. Sens. Environ. 8, 127-150 (1979) [doi:10.1016/00344257(79)90013-0].

[11]P.S. Thenkabail, A.D. Ward, J.G. Lyon, and C.J. Merry, "Thematic Mapper vegetation indices for determining soybean and corn crop growth parameters," Photogram. Engin. and Rem. Sens. 60 (4), 437-442 (1994).

[12]P.S. Thenkabail, "Biophysical and yield information for precision farming from near-real-time and historical Landsat TM images," Int. J. Rem. Sens. 24(14), 28792904 (2003) [doi:10.1080/01431160710155974].

[13] P.S. Thenkabail, C.M. Biradar, H. Turral, P. Noojipady, Y.J. Li, J. Vithanage, V. Dheeravath, M. Velpuri, M. Schull, X. L. Cai, R. Dutta, "An Irrigated Area Map of the World (1999) derived from Remote Sensing," Research Report 105. International Water Management Institute. pp. 1-74 (2006).

[14] P.S. Thenkabail, C.M. Biradar, P. Noojipady, V. Dheeravath, Y.J. Li, M. Velpuri, M.Gumma, G.P.O. Reddy, H. Turral, X. L. Cai, J. Vithanage, M. Schull, and R. Dutta, "Global Irrigated Area Map (GIAM) for the End of the Last Millennium Derived from Remote Sensing," Int. J. Rem. Sens. xx, xx-xx (2008) (in press).

[15] P.J. Sellers, "Canopy reflectance, photosynthesis, and transpiration. The role of biophysics in the linearity of their interdependence," Rem. Sens. Environ. 21,143183 (1987) [doi:10.1016/0034-4257(87)90051-4].

[16] A.A. Gitelson, and M.N. Merzlyak, "Quantitative estimation of chlorophyll-a using reflectance spectra: experiments with autumn chestnut and maple leaves," $J$. Photochem. Photobiol. 22, 247-252 (1994) [doi:10.1016/1011-1344(93)06963-4]. 
[17] C.J. Tucker and P.J. "Sellers, Satellite remote sensing of primary production," Int. J. Rem. Sens. 7, 1395-1416 (1986) [doi:10.1080/01431168608948944].

[18]D.S. Bartlett, M.A. Hardisky, R.W. Johnson, M.F. Gross, V. Klemas, and J.M. Hartman, "Continental scale variability in vegetation reflectance and its relationship to canopy morphology," Int. J. Rem. Sens. 9, 1223-1241 (1988) [doi:10.1080/01431168808954930].

[19]F. Baret, G. Guyot, and D.J. Major, "TSAVI: A vegetation index which minimizes soil brightness effects on LAI and APAR estimation," in Proc. IGARRS'90, 13551358, (1989).

[20] C.J. Wiegand, A.J. Richardson, D.E. Escobar, and A.H. Gerbermann, "Vegetation indices in crop assessments," Rem. Sens. Environ. 35,105-119 (1991) [doi:10.1016/0034-4257(91)90004-P].

[21]P.S. Thenkabail, A.D. Ward, and J.G. Lyon, "Impacts of agricultural management practices on soybean and corn crops evident in ground-truth data and thematic mapper vegetation indices," Trans. Ame. Soc. Agri. Engine. 37, 989-995 (1994).

[22] P.S. Thenkabail, A.D. Ward, and J.G. Lyon, "Landsat-5 Thematic Mapper models of soybean and corn crop characteristics," Inte. J. Rem. Sens. 15, 9-61 (1995).

[23] J.L. Monteith, "Solar radiation and productivity in tropical ecosystems," J. Appl. Eco. 9, 747-766 (1972) [doi:10.2307/2401901].

[24] J.L. Monteith, "Climate and the efficiency of crop production in Britain," Philosop. Trans. Royal Soc. Lond. 281, 277-294 (1977) [doi:10.1098/rstb.1977.0140].

[25] C.S. Potter, J.T. Randerson, C.B. Field, P.A. Matson, P.M.V. Vitousek, H.A. Mooney, A.K. Steven, "Terrestrial ecosystem production: a process model based on global satellite and surface data," Glob. Biogeochem. Cyc. 7, 811-841 (1993) [doi:10.1029/93GB02725].

[26] C.B. Field, J.T. Randerson, and C.M. Malmström, "Global net primary production: combining ecology and remote sensing," Rem. Sens. Environ. 51, 74-88 (1995) [doi:10.1016/0034-4257(94)00066-V].

[27] D.B. Lobell, J.A. Hicke, G.P. Asner, C.B. Field, C.J. Tucker, S.O. Los, "Satellite estimates of productivity and light use efficiency in United States agriculture," Glob. Chan. Bio. 8, 722-735 (2002) [doi:10.1046/j.1365-2486.2002.00503.x].

[28] B.D. Lobell, G. P. Asner, A,L, Ortiz-Monasterio, and I. J. Benning, "Remote sensing of regional crop production in the Yaqui Valley, Mexico: estimates and uncertainties," Agri. Eco. Environ. 94, 205-220. (2003) [doi:10.1016/S0167$\underline{\text { 8809(02)00021-X]. }}$.

[29] W.G.M. Bastiaanssen, and S. Ali, "A new crop yield forecasting model based on satellite measurements applied across the Indus Basin. Pakistan," Agri. Eco. Environ. 94, 321-340 (2003) [doi:10.1016/S0167-8809(02)00034-8].

[30] G.B. Samarasinghe, "Growth and yields of Sri Lanka's major crops interpreted from public domain satellites," Agri. Water Manag. 58, 145-157 (2003) [doi:10.1016/S0378-3774(02)00130-0].

[31] V.K. Dadhwal, "Remote sensing applications for agriculture: retrospective and perspective," Proce. Indian Society of Remote Sensing, 99, 11-22 (1999).

[32] S.N. Goward, and K.F. Huemmrich, "Vegetation canopy PAR absorptance and the normalized difference vegetation index: an assessment using the SAIL model," Rem. Sens. Environ. 39, 119-140 (1992) [doi:10.1016/0034-4257(92)90131-3].

[33] F. Maselli, C. Conese, L. Petkov, and M. A. Gilabert, "Use of NOAA AVHRR NDVI data for environmental monitoring and crop forecasting in the Sahel. Preliminary results," Int. J. Rem. Sens. 13, 2743-2749 (1992) [doi:10.1080/01431169208904076]. 
[34] M. S. Rasmussen, "Assessment of millet yields and production in northern Burkina Faso using integrated NDVI from the AVHRR," Int. J. Rem. Sens. 13, 3431-3442 (1992) [doi:10.1080/01431169208904132].

[35] N. A. Quarmby, M. Milnes, T. L. Hindle, and N. Silleos, "The use of multi-temporal NDVI measurements from AVHRR data for crop yield estimation and prediction," Int. J. Rem. Sens. 14, 199-210 (1993) [doi:10.1080/01431169308904332].

[36] M. J. Hayes, and W. L. Decker, "Using NOAA AVHRR data to estimate maize production in the United States corn belt," Int. J. Rem. Sens. 17, 3189-3200 (1996) [doi: $10.1080 / 01431169608949138$ ].

[37] F.N. Kogan, "Global drought watch from space," Bull. Ame. Meteoro. Soc. 78, 621636 (1997) [doi:10.1175/1520-0477(1997)078<0621:GDWFS $>2.0 . C O ; 2]$.

[38] J.B. Passioura, "Environmental biology and crop improvement," Funct. Plant Bio. 29, 537-546 (2002) [doi:10.1071/FP02020].

[39] L.S. Unhanai, and F.N. Kogan, "Drought monitoring and corn yield estimation in Southern Africa from AVHRR data," Rem. Sens. Environ. 63, 219-232 (1998) [doi:10.1016/S0034-4257(97)00132-6].

[40] T. E. Engman, "Recent advances in remote sensing in hydrology. U.S. National Report to IUGG, 1991-1994," Rev. Geophys. Suppl. AGU, 33 (1995) (http://www.agu.org/revgeophys/engman00/engman00.html).

[41] J.L. Wright, R.G. Allen, and T.A., Howell, "Conversion between evapotranspiration references and methods," Proce. Fourth National Irrigation Symposium ASAE, Phoenix, AZ, USA (2000).

[42] P.S. Kashyap, and R.K. Panda, "Evaluation of evapotranspiration methods and development of crop-coefficients for potato crop in a sub-humid region," Agri Water Manage. 50, 9-25 (2001) [doi:10.1016/S0378-3774(01)00102-0].

[43] Kassam and M. Smith, "FAO methodologies on crop water use and crop water productivity," Proce. Expert Meeting on Crop Water Prod. Rome, Italy, (2001).

[44] R.G. Allen, S.L. Pereira, D. Raes, and M. Smith, "Crop evapotranspiration: guidelines for computing crop water requirements," FAO Irrigation and Drainage Paper, 56, FAO, Rome (1998).

[45] I.A. Walter, R.G. Allen, R. Elliott, M.E. Jensen, D. Itenfisu, B. Mecham, T.A. Howell, R. Snyder, P. Brown, S. Echings, T. Spofford, M. Hattendorf, R.H. Cuenca, J.L. Wright, and D. Martin, "ASCE's Standardized Reference Evapotranspiration Equation," Proce. National Irrigation Symposium, ASAE, Phoenix, AZ, (2000).

[46] W.P. Kustas, and C.S.T. Daughtry, "Estimation of the soil heat flux/net radiation ratio from multispectral data," Agri. For. Meteoro. 49, 205-223 (1990) [doi:10.1016/0168-1923(90)90033-3].

[47] K.S. Humes, W.P. Kustas, and M.S. Moran, "Use of remote sensing and reference site measurements to estimate instantaneous surface energy balance components over a semiarid rangeland watershed," Water Res. Res. 30, 1363-1373 (1994) [doi:10.1029/93WR03082].

[48] G.W. Kite, and P. Droogers, "Comparing evapotranspiration estimates from satellites, hydrological models and field data," J. Hydro. 209, 3-18. (2000) [doi:10.1016/S0022-1694(99)00195-X].

[49] T.J. Schmugge, W.P. Kustas, J.C. Ritchie, T.J. Jackson, and A.Rango, "Remote sensing in hydrology," Adv. Water Res. 25 (8-12), 1367-1385. (2002)

[50] D. Courault, B. Seguin and O. Olioso, "Review to estimate evapotranspiration from remote sensing data: some examples from the simplified relationship to the use of atmospheric models," Workshop on Remote Sensing of ET for Large Regions, ICID. Montpellier, France, (2003). 
[51] T.G. Van Niel, and T.R., McVicar, "Current and potential uses of optical remote sensing in rice-based irrigation systems: a review," Aus. J. Agri. Res. 55, 155-185 (2004) [doi:10.1071/AR03149].

[52] W.G.M. Bastiaanssen, M. Menenti, R.A. Feddes and A.A.M. Holtslag, "The Surface Energy Balance Algorithm for Land (SEBAL): Part 1 formulation," $J$. Hydro. 212-213, 198-210 (1998) [doi:10.1016/S0022-1694(98)00253-4].

[53] W. G. M. Bastiaanssen, S. Thiruvengadachari, R. Sakthivadivel, and D. J. Molden, "Satellite Remote Sensing for Estimating Productivities of Land and Water," Water Res. Devel. 15 (1-2), 181-196 (1999) [doi:10.1080/07900629949005].

[54] R. G. Allen, M. Tasumi, and R. Trezza, "Satellite-Based Energy Balance for Mapping Evapotranspiration with Internalized Calibration (METRIC) Model," $J$. Irri. Drain. Engin. 133 (4), 380-394 (2007) [doi:10.1061/(ASCE)07339437(2007)133:4(380)].

[55] G.B. Senay, and J. Verdin, "Using a GIS-Based Water Balance Model to Assess Regional Crop Performance," Proc. Fifth International Workshop on Application of Remote Sensing in Hydrology, Montpellier, France (2001).

[56] G.B. Senay, and J. Verdin, "Characterization of Yield Reduction in Ethiopia Using a GIS-Based Crop Water Balance Model," Can. J. Rem. Sens. 29(6), 687-692 (2003).

[57] G. B. Senay, M. Budde, J.P. Verdin and A. M. Melesse, "A coupled Remote Sensing and Simplified Surface Energy Balance approach to estimate actual evapotranspiration from irrigated fields," Sensors. 7, 979-1000 (2007).

[58] P.S. Thenkabail, C.M. Biradar, P. Noojipady, X.L. Cai, V. Dheeravath, Y.J. Li, M. Velpuri, M. Gumma, and S. Pandey, "Sub-pixel irrigated area calculation methods," Sensors. 7, 2519-2538 (2007).

[59] A. Platonov, P.S. Thenkabail, C.M. Biradar, X. Cai, M. Gumma, V. Dheeravath, Y. Cohen, V. Alchanatis, N. Goldshlager, E. Ben-Dor, J. Vithanage, H. Manthrithilake, Sh. Kendjabaev, and S. Isaev, "Water Productivity Mapping (WPM) using Landsat ETM+ Data for the Irrigated Croplands of the Syrdarya River Basin in Central Asia," Sensors. xx, xx-xx (in review).

Chandrashekhar M. Biradar is researcher (remote sensing) at Center for Spatial Analysis, University of Oklahoma, USA. Prior to this he was at the Institute for the Study of Earth, Oceans and Space, UNH. He is the author of more than 25 peer-reviewed scientific papers and book chapters and co-editor of two books. His current research interests include global land remote sensing; land use and land cover change, cropping intensity, climate change and ecology of infectious diseases.

Prasad S. Thenkabail is a research geographer at the U.S. Geological Survey, Flagstaff, Arizona, USA. Prior to this he was a principal researcher and head of remote sensing at the International Water Management (IWMI). Prasad has $23+$ years experience working as a well recognized International expert in Remote Sensing and Geographic Information Systems (RS/GIS) and its applications to natural resources management, sustainable development, and environmental studies. He lead the global irrigated area mapping project and water productivity mapping project at IWMI. Prasad has worked in over 25 Countries in Africa, Asia, Middle-East, and North America. He has $60+$ publications in major International journals. He is currently on the Landsat Science Team, editorial board of Remote Sensing of Environment (RSE), and one of the Associate Editor-in-Chief of Journal of Spatial Hydrology (JoSH)

Alexander Platonov is a National Researcher of the IWMI, Central Asia sub-office in Tashkent, Uzbekistan. He has 10 years experience as a GIS/RS specialist in projects for agricultural land and water resources management in Central Asian countries. 
Xiangming Xiao is a Professor at University of Oklahoma, USA. He received his B.Sc. degree in Biology in 1982 from Xiamen University, China, and M.Sc. degree in Ecology in 1987 from University of Science and Technology, China, and Ph.D. degree in Ecosystem Science in 1994 from Colorado State University, USA. He has been author and co-authors for over 80 peer-reviewed scientific papers and book chapters. His current research interests include global land remote sensing, land use and land cover change, carbon cycle, water cycle, and ecology and epidemiology of infectious diseases.

Roland Greeken Currently works for GTZ in Chad, Sudan, and other African Nations. Earlier to this Roland worked as a Associate Research Scientist with the Department of Geology and Geophysics, Yale University, New Haven, CT. Roland's expertises include remote sensing and modeling. He developed fourier series algorithm for vegetation dynamics analysis. Roland has extensive experience in applying remote sensing to land and water resources.

Praveen Noojipady is a $\mathrm{PhD}$ student at the Department of Geography, University of Maryland, College Park. He received his Bachelor and Master of Engineering from Bangalore University in 2000 and 2004 respectively. He is the author of more than 10 journal papers and his research interests include global land cover and land use dynamics.

Hugh Turral was Theme Leader for Basin Water Management (Theme 1) at the International Water Management Institute, Colombo, from 2003 to 2007. He is a researcher in irrigation and water resources management, with a particular interest in the application of remote sensing to water management issues. He is now starting a new career as a film-maker in Australia.

Jagath Vithanage is a national researcher at IWMI, Colombo, Sri Lanka. 